\title{
Molecular characterization of methicillin- resistant Staphylococcus aureus strains by spa typing and pulsed field gel electrophoresis methods
}

\author{
Tülin Güven Gökmen ${ }^{1,4}$, Yıldız Kalayci ${ }^{2^{*}}$ (D, Akgün Yaman ${ }^{3}$ and Fatih Köksal ${ }^{3}$
}

\begin{abstract}
Background: Rapid detection of sources and transmission routes by molecular methods provides key data for risk management of methicillin-resistant Staphylococcus aureus-induced infections acquired in both the community and hospitals. This study aimed to determine the clonal relationship of methicillin-resistant S. aureus strains isolated from our hospital by pulsed-field gel electrophoresis (PFGE) and Staphylococcal protein A (spa) typing methods and to identify the predominant clones in Cukurova Region, Turkey.

Results: All isolates analyzed by PFGE were distributed among 11 clusters. Clusters $A(n=19)$ and $B(n=27)$ were $84.1 \%$ similar and accounted for $61 \%$ of all samples. All isolates were distributed among 18 spa types, with the most common type being t030 with 31 isolates (41.3\%), followed by t223 with nine isolates (12\%) and t127 with seven isolates (9.3\%).

Conclusions: We found that t030 was the most common spa type in the area where the study was conducted, as also previously shown in studies undertaken in Turkey. However, the rate of t030 in our study was below the rates reported in the literature. We also detected some rare or sporadic spa types like t127, which has not been previously defined in our country. We consider that the spa typing and PFGE methods are useful for research on clonal relations in monitoring the changing prevalent clones in specific regions.
\end{abstract}

Keywords: spa typing, PFGE, MRSA, Protein a, Epidemiology

\section{Background}

Staphylococcus aureus, which can be found as floral bacteria in the skin and mucous membranes of humans, have the ability to develop resistance in a short time to broad-spectrum antibiotics, such as the $\beta$-lactam group of antibiotics, aminoglycosides, and quinolones that are widely used for the treatment of severe infections in clinical practice [1]. Methicillin-resistant S. aureus, first reported in the UK in 1961, remains to be a serious problem for hospitals. Various hospital-acquired methicillin-resistant $S$. aureus clones have spread across the world, becoming a major cause of mortality and morbidity in hospitals. The community-acquired MRSA clones first appeared at the

\footnotetext{
* Correspondence: tulinguven01@hotmail.com

${ }^{2}$ Microbiology Laboratory, Adana City Hospital, 01380 Adana, Turkey Full list of author information is available at the end of the article
}

beginning of the 1990s; then, some successful clones spread to hospitals and became predominant in the USA and Europe [2].

In order to identify the epidemiologic characteristics of MRSA strains and more importantly to study the evolution and spreading of epidemic clones, there is a need to employ applicable and reproducibility molecular methods with sufficient discriminative power that are capable of monitoring changes in time. The methods mostly used for this purpose include pulsed-field gel electrophoresis (PFGE), Multilocus Sequence Typing (MLST), staphylococcal cassette chromosome mec (SCCmec) typing, and staphylococcal protein A (spa) typing [3]. It is agreed that the PFGE method is the gold standard particularly for the short-term surveillance of $S$. aureus typing $[3,4]$. Despite the difficulties in reproducibility

(c) The Author(s). 2018 Open Access This article is distributed under the terms of the Creative Commons Attribution 4.0 International License (http://creativecommons.org/licenses/by/4.0/), which permits unrestricted use, distribution, and reproduction in any medium, provided you give appropriate credit to the original author(s) and the source, provide a link to the Creative Commons license, and indicate if changes were made. The Creative Commons Public Domain Dedication waiver (http://creativecommons.org/publicdomain/zero/1.0/) applies to the data made available in this article, unless otherwise stated. 
and interlaboratory reliability, many countries have established a nomenclature for their local pulsotypes through the standardization of PFGE protocols $[5,6]$. Sequence-based methods, such as MLST and spa typing are highly reproducible among laboratories, can easily be standardized, and have common names worldwide, rendering these methods more advantageous compared to the PFGE method [6,7]. Although MLST has a lower distinction power than spa typing, it is a superior method for monitoring clonal evolution. The spa typing method, on the other hand, not only provides an sufficient discriminative power but also has the advantage of being cost-effective as it targets a single locus [8]. Moreover, the analysis of spa types using the based upon repeat patterns (BURP) algorithm has been found highly comparable to MLST [9].

This study aimed to detected the clonal relationship of MRSA strains isolated from clinical samples in our hospital by pulsed-field gel electrophoresis (PFGE) and Staphylococcal protein A (spa) typing methods and to determinated the predominant clones in Cukurova Region, Turkey.

\section{Methods}

A total of 197 non-duplicate Staphylococcus aureus (S.aureus) in 311 Staphylocoocus spp. isolates from different patients were collected between November-2012 and December-2013 from the clinical samples sent to the Central Laboratory of Çukurova University, Balcali Hospital, Turkey (Tables 1 and 2).

The identification and antibiotic sensitivity tests of the strains were performed on the Vitek 2 automated system for oxacillin, gentamicin, ciprofloxacin, erythromycin, clindamycin, linezolid, teicoplanin, vancomycin, imipenem, tetracycline, tigecycline, fosfomycin, fusidic acid, rifampicin and trimethoprim/sulfamethoxazole. Confirmation of 75 isolates with methicillin resistance was confirmed by the Kirby-Bauer disc diffusion method for cefoxitin. Breakpoints were applied according to the 2016

Table 1 Study Patients Characteristics and Epidemiologic Classification

\begin{tabular}{lll}
\hline Characteristics & $n=75$ & percent \\
\hline Sex: F/M & $23 / 52$ & $30.6 / 69.4$ \\
Age Distribution: & & \\
$\quad$ Median/IQR & $34 / 0-85$ & - \\
Inpatients/Outpatients & $64 / 11$ & $85.3 / 14.7$ \\
Samples & & \\
Wound IP/OP & $20 / 10$ & $26.7 / 13.3$ \\
Tracheal aspirate IP/OP & $31 /-$ & $41.3 /-$ \\
Blood IP/OP & $11 /-$ & $14.7 /-$ \\
Urine IP/OP & $2 / 1$ & $2.7 / 1.3$ \\
\hline
\end{tabular}

$F$ Female, $M$ Male, IQR Interquartile range, IP Inpatients, $O P$ Outpatients
Table 2 Distribution of isolates to hospital units

\begin{tabular}{|c|c|}
\hline Unit & $\begin{array}{l}\text { Isolates } \\
\text { number (\%) }\end{array}$ \\
\hline Pediatric Intensive Care Unit & $10(13 \%)$ \\
\hline Reanimation Intensive Care Unit & $10(13 \%)$ \\
\hline Internal Medicine Intensive Care Unit & $5(6.7 \%)$ \\
\hline Chest Disease Unit & $4(5.3 \%)$ \\
\hline Infectious Disease Unit & $4(5.3 \%)$ \\
\hline Dermatology Unit & $4(5.3 \%)$ \\
\hline Burn Unit & $3(4 \%)$ \\
\hline Pediatric Oncology Unit & $2(2.7 \%)$ \\
\hline Pediatric Haematology Unit & $2(2.7 \%)$ \\
\hline Pediatric Infectious Disease Unit & $2(2.7 \%)$ \\
\hline Pediatric 2 Unit & $2(2.7 \%)$ \\
\hline Nephrology Unit & $2(2.7 \%)$ \\
\hline Urology Unit & $2(2.7 \%)$ \\
\hline Neurology Intensive Care Unit & $2(2.7 \%)$ \\
\hline Endocrinology Unit & $2(2.7 \%)$ \\
\hline Plastic and Reconstructive Surgery Unit & $2(2.7 \%)$ \\
\hline Haematology Unit & $2(2.7 \%)$ \\
\hline Neonatal Intensive Care Unit & $1(1.3 \%)$ \\
\hline Pedatric Allergy and Immunology Unit & $1(1.3 \%)$ \\
\hline Neurosurgery Unit & $1(1.3 \%)$ \\
\hline Ortopedics and Traumatology Unit & $1(1.3 \%)$ \\
\hline Gynecology and obstetrics unit & $1(1.3 \%)$ \\
\hline General Surgery Unit & $1(1.3 \%)$ \\
\hline Pediatric Infectious Disease Unit 2 & $1(1.3 \%)$ \\
\hline Oncology Unit & $1(1.3 \%)$ \\
\hline Ophtalmology Unit & $1(1.3 \%)$ \\
\hline Pediatric Gastroenterology Unit & $1(1.3 \%)$ \\
\hline Pediatric Surgery Unit & $1(1.3 \%)$ \\
\hline Neurology Unit & $1(1.3 \%)$ \\
\hline Urology Unit 2 & $1(1.3 \%)$ \\
\hline Neurosurgery Unit & $1(1.3 \%)$ \\
\hline Pediatrics Cardiovascular surgery Unit & $1(1.3 \%)$ \\
\hline Total & 75 \\
\hline
\end{tabular}

European Committee on Antimicrobial Susceptibility Testing (EUCAST) guidelines [10].

The SmaI-PFGE was performed as described in a previous study [11]. The band profiles were analyzed using GelCompar II software (version 4.0; Applied Maths, Sint-Martens-Latem, Belgium).

Deoxyribonucleic acid (DNA) was extracted from isolates by mechanical lysis using a Mickle tissue disintegrator (Mickle Laboratory Engineering Co. Ltd.). Polymerase chain reaction (PCR) was applied to DNA extracts using the spa-1113f (5'TAA AGA CGA TCC TTC GGT GAG C3') 
Table 3 Antibiotic resistance of MRSA isolates

\begin{tabular}{|c|c|c|c|c|c|c|c|c|c|c|c|c|c|c|}
\hline Antibiotics & CIP & DA & $E$ & FOS & FA & $\mathrm{CN}$ & LZD & MOX & RA & TEl & TE & TIG & SXT & $\overline{V A}$ \\
\hline Resistant strains number & 39 & 43 & 46 & 26 & 5 & 36 & - & 32 & 39 & - & 47 & - & 13 & - \\
\hline$\%$ & 52 & 57.3 & 61.3 & 34.6 & 6.7 & 48 & 0 & 42.7 & 52 & 0 & 62.6 & 0 & 17.3 & 0 \\
\hline
\end{tabular}

and spa-1514r (5'CAG CAG TAG TGC CGT TTG CTT3') primers [12]. The PCR products were purified using SentroPure ${ }^{\circ}$ DNA purification kit (Sentromer DNA Technologies LLC, Istanbul, Turkey) according to the kit protocol. Then, cycle sequencing was undertaken using BigDye ${ }^{\oplus}$ Terminator v3.1 cycle sequencing kit (Applied Biosystems, CA, USA). The products were purified with ZR DNA Sequencing Clean-up Kit ${ }^{\mathrm{tm}}$ (Zymo Research, CA, USA) as recommended in the protocol. The DNA sequence analysis of the spa gene region was performed using ABI Prism 310 DNA sequencer (Applied Biosystems, CA, USA).

The raw data was processed with Sequencing Analysis Software version 5.1, and the spa types were identified by Ridom StaphType TM (Ridom GmbH, Würzburg, Germany) software. Using the BURP algorithm in the software, spa types were grouped based on six or less repeat differences.

Table 4 Distribution of test isolates by their spa types according to samples and spa types

\begin{tabular}{|c|c|c|c|c|c|c|c|c|c|c|}
\hline \multirow{2}{*}{$\begin{array}{l}\text { Spa } \\
\text { types }\end{array}$} & \multirow{2}{*}{$\begin{array}{l}\text { PFGE } \\
\text { types }\end{array}$} & \multicolumn{4}{|c|}{ Outpatients } & \multicolumn{4}{|c|}{ Inpatients } & \multirow{2}{*}{$\begin{array}{l}\text { Samples } \\
\text { Number (\%) }\end{array}$} \\
\hline & & $\overline{\mathrm{TA}}$ & Wound & Blood & $\overline{\text { Urine }}$ & $\overline{\mathrm{TA}}$ & Wound & Blood & $\overline{\text { Urine }}$ & \\
\hline \multirow[t]{3}{*}{ t030 } & $A$ & - & - & - & - & 11 & 3 & 5 & 1 & 31 (41.3\%) \\
\hline & B & - & - & - & 1 & 8 & 1 & - & - & \\
\hline & $C$ & - & - & - & & & 1 & & & \\
\hline \multirow[t]{3}{*}{ t223 } & G & - & - & - & - & 1 & 3 & 1 & 1 & 9 (12\%) \\
\hline & $\mathrm{H}$ & - & - & - & - & - & - & 2 & - & \\
\hline & J & - & - & - & - & 1 & - & - & - & \\
\hline \multirow[t]{2}{*}{ t127 } & B & - & 2 & - & - & 3 & - & - & - & 7 (9.3\%) \\
\hline & $\mathrm{F}$ & - & - & - & - & 2 & - & - & - & \\
\hline \multirow[t]{3}{*}{ t037 } & B & - & - & - & - & - & 1 & - & - & $6(8 \%)$ \\
\hline & D & - & - & - & - & - & 1 & 2 & - & \\
\hline & G & - & - & - & - & - & 1 & 1 & - & \\
\hline \multirow[t]{2}{*}{ t005 } & G & - & 2 & - & - & - & 1 & - & - & $4(5.3 \%)$ \\
\hline & M & - & 1 & - & - & - & - & - & - & \\
\hline t002 & B & - & 1 & - & - & - & 1 & - & - & $2(2.7 \%)$ \\
\hline \multirow[t]{2}{*}{ t267 } & G & - & 1 & - & - & - & - & - & - & $2(2.7 \%)$ \\
\hline & $N$ & - & - & - & - & - & 1 & - & - & \\
\hline t008 & B & - & - & - & - & - & 2 & - & - & $2(2.7 \%)$ \\
\hline t016 & B & - & - & - & - & - & 2 & - & - & $2(2.7 \%)$ \\
\hline t790 & B & - & - & - & - & 1 & 1 & - & - & $2(2.7 \%)$ \\
\hline t304 & $C$ & - & 1 & - & - & - & - & - & - & $1(1.3 \%)$ \\
\hline t459 & D & - & - & - & - & 1 & - & - & - & $1(1.3 \%)$ \\
\hline t359 & K & - & - & - & - & - & 1 & - & - & $1(1.3 \%)$ \\
\hline t311 & A & - & - & - & - & - & 1 & - & - & $1(1.3 \%)$ \\
\hline t091 & G & - & 1 & - & - & - & - & - & - & $1(1.3 \%)$ \\
\hline t7576 & A & - & - & - & - & 1 & - & - & - & $1(1.3 \%)$ \\
\hline t2816 & $N$ & & 1 & - & - & - & - & - & - & $1(1.3 \%)$ \\
\hline t4565 & M & - & - & - & - & - & 1 & - & - & $1(1.3 \%)$ \\
\hline Total & & 11 & & & & 64 & & & & 75 (100\%) \\
\hline
\end{tabular}




\section{Results}

In this study, we determined antibiotic resistance of 75 MRSA isolates by the Vitek 2 automated system routinely used in the laboratory (Table 3 ).

All of the isolates were evaluated with PFGE and spa typing to reveal their epidemiology in our region. When the similarity cut-off value was taken as $85 \%$, 75 isolates were divided into 11 main clusters by the PFGE method. The largest cluster was cluster B with 27 members, followed by cluster A with 19 members. Clusters J, K, L and $\mathrm{N}$ had a single isolate. Clusters $\mathrm{A}$ and $\mathrm{B}$ constituted $61.3 \%$ of all isolates with a similarity of $84.1 \%$ according to PFGE.
The most common spa type was t30 with 31 isolates (41.3\%), followed by t223 with nine isolates (12\%) and t127 (9.3\%) with seven isolates. Eight of the isolates were singletons (Table 4).

All the t030 isolates were in clusters A and B, except for one isolate in cluster C. Clusters A and B contained nine more spa types. The strains in cluster G, the third largest cluster, were distributed among five different spa types.t223 was the second most prevalent spa type and was distributed among clusters G, $\mathrm{H}$ and $\mathrm{J}$, showing $80.1 \%$ similarity in SmaI-PFGE. The third common spa type, t127, was included in cluster B (Table 5).

Table 5 Comparison of S.aureus strains with PFGE and spa typing

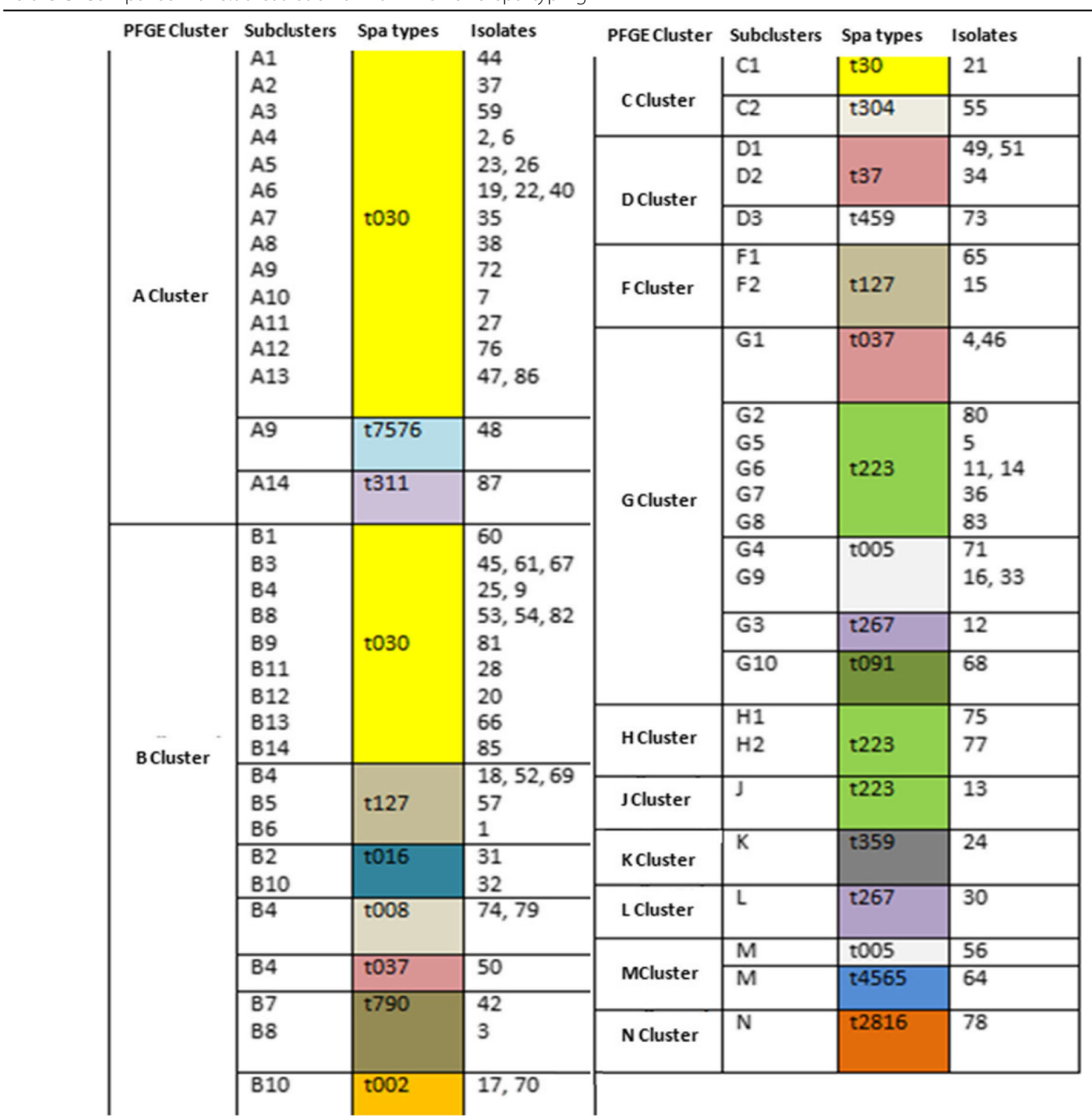


The spa types were divided into five clusters by the BURP analysis. Cluster 1 [Clonal Complex 005 (CC005)] consisted of $\mathrm{t} 790, \mathrm{t} 223, \mathrm{t} 4565, \mathrm{t} 2816$ and $\mathrm{t} 016$ originating from t005. Cluster 2 (CC459) contained t37, t30 and t7576 originating from $\mathrm{t} 459$ (Fig. 1).

\section{Discussion}

Although many MRSA genotypes and clonal clusters have been identified in different biogeographic regions, it has been generally determined that certain gene clones are predominant. In the United States, community-associated ST8-spa t008 (USA300) and ST5-spa t002 clones are predominant, while ST22-spa t032, mostly associated with hospital, is more commonly seen [6,13-15]. In France and Belgium, however, it is reported that the ST8-spa t008 clone, defined as the community origin similar to the USA, is widespread [14, 15]. In Bulgaria and the Balkan countries, such as Romania and Turkey, ST239-spa t030 is the predominant spa type [14]. It has been shown in studies conducted in Asia and Far East countries that ST239-spa t030, ST239-spa t037 and ST5-spa t002 are the most common types [16-18].

In the current study, 75 MRSA clinical isolates were examined. Twenty-eight isolates (37.3\% of all isolates) were collected from intensive care units where MRSA infections were most prevalent [19]. Clonal relationship of MRSA strains were determined by pulsed-field gel electrophoresis (PFGE) and Staphylococcal protein A (spa) typing methods. In many studies similar to our study, MLST method was used together with spa typing and PFGE methods. However, MLST studies of these isolates has to be postpone due to funding reasons.

The isolates were distributed among 11 clusters with PFGE and 18 clusters with spa typing. Spa typing revealed that 31 isolates $(41.3 \%)$ belonged to type t030. The other spa types detected were t223 (12\%) with nine isolates, t127 (9.3\%) with seven isolates, t037 (8\%) with six isolates, and t005 (5.3\%) with four isolates. This finding indicates that type t030 has high prevalence (41.3\%) in Turkey, as in Asian and Balkan countries [14, 17].

t030 isolates were collected in clusters A and B, which were $80 \%$ similar to each other according to the PFGE band profiling. The second most frequent spa type, t223, was found in clusters $\mathrm{G}, \mathrm{H}$ and $\mathrm{J}$, which were $80.1 \%$ similar as revealed by PFGE. The third spa type, t127, was included in cluster B. Rare or sporadic spa types showed a heterogeneous distribution with PFGE. In a Finnish study, 90\% of the most common spa types, t172 and t067, were clustered in FIN-4 and FIN-16 PFGE patterns, respectively.
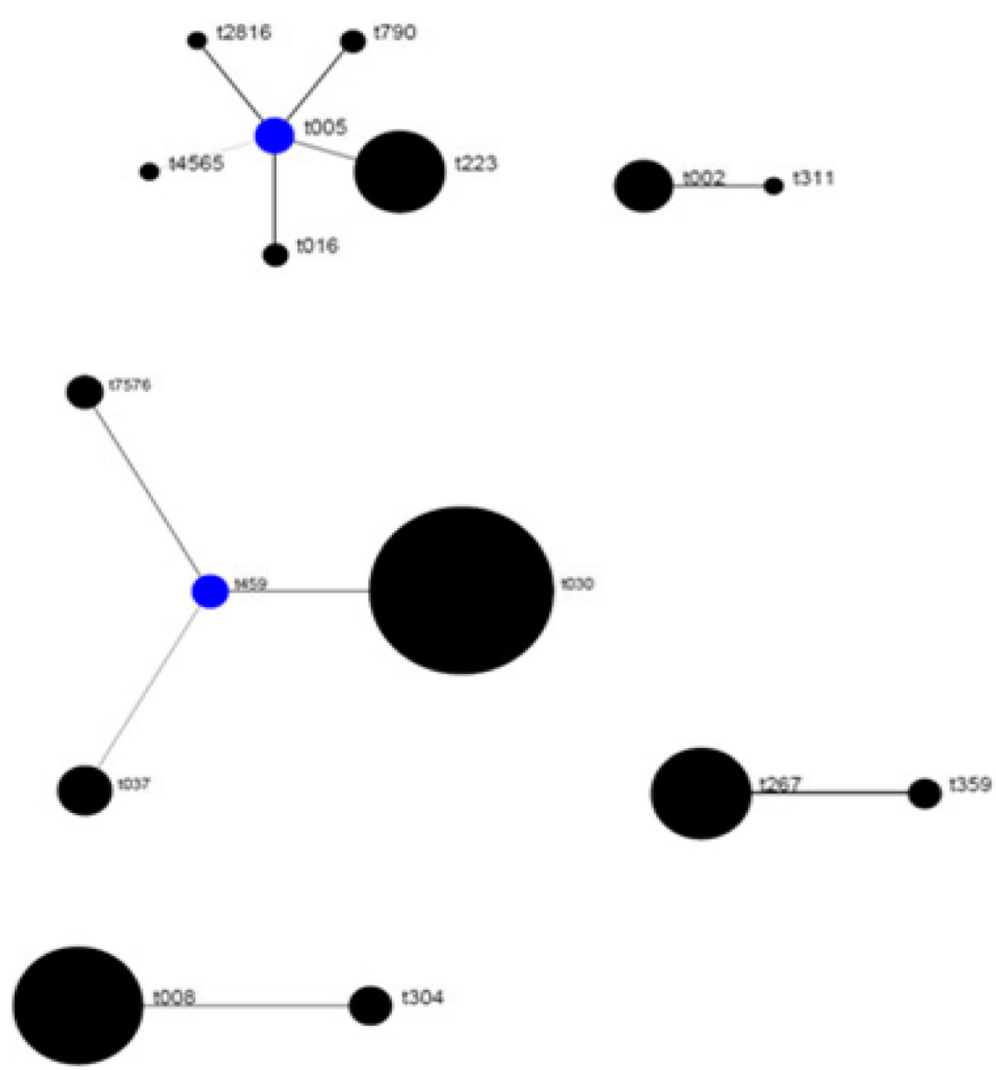

Fig. 1 Distribution of spa clonal complexes (BURP analysis) 
Similar to our study, rare spa types were associated with more than one PFGE cluster [20].

The ST239 clone containing spa t030 was first found to be widely distributed in a large number of patients in Brazil; therefore, this clone was called the Brazilian clone. Later spreading to the neighboring South American countries, such as Argentina, Chile, Uruguay, and European countries, including Portugal, Czech Republic, and Greece, the ST239 clone is now epidemically seen in most Asian countries [17, 21].

In a study conducted in China, it was reported that the predominant clone from 1994 to 2000 was ST239-spa t037 with $92.6 \%$ prevalence, but after 2000, this clone rapidly decreased and replaced by ST239-spa t030. In this study, spa types t30 and t37 were located in unrelated clusters by PFGE [17].

In Turkey, the first spa t030 isolates were identified from nine blood cultures in 2003-2004. Then, in a study conducted with 54 strains isolated from invasive infections (92\% blood cultures) in eight university hospitals between 2005 and 2006, 89\% of the strains were identified as spa t030. The rate of spa t030 in the current study was below the values given in these two studies. We consider that this difference may be due to the variances in the samples.

In another study, 48 MRSA isolates were divided into 14 PFGE clusters and the spa type of all isolates except two was spa t030 which collected in 3 months. As noted in the study, because the samples reflected a period of 3 months, genetic diversity may be limited [22-24].

However, our study, which shows that some communitybased isolates are beginning to be seen in hospitals at increasing frequency, will be a guide for future studies.

In a 2008-2009 study conducted in 12 cities in Turkey, the most common PFGE pattern was found to be Pulsotype A (91.4\%) and the most common spa type was t030 (85.1\%) among the 397 MRSA isolates collected. This clone was called 'TR09'. However, in the same study, it was determined that among the 91 isolates obtained in 2011 , the rate of $\mathrm{t} 30$ decreased to $70.3 \%$ and the number of new sporadic types increased. The reduction in the rate of spa t030 in this study supported our work. This study showed that the most common community-associated MRSA clone was ST737-spa t005, which was named "TR10" [25]. We also found the prevalence of the t005 type as $5.3 \%$. In addition, we also detected $\mathrm{t} 790, \mathrm{t} 4565$, t2816, and the second most common spa type t223 in our study, clustered in the same clonal complex with t005 by BURP analysis.

In our study, we identified $\mathrm{t} 127$ as the third most commonly defined spa type, which had not been previously defined in Turkey. Methicillin-sensitive and resistant t127 clones have been isolated from humans, food and animals in various studies and are considered community-associated [26-28].

\section{Conclusion}

In conclusion, among the MRSA strains, spa t030 was predominant in our region, as previously reported for other regions in Turkey. The most common spa types were closely clustered in PFGE. In the current study, spa t127, which is common among community-acquired isolates, was identified for the first time in Turkey. Therefore, it is considered that MRSA surveillance is absolutely required to constantly monitor clones across the world. Furthermore, it is beneficial to use the spa typing method and PFGE in the research of clonal relations to follow the changing clones that are prevalent in Turkey.

\section{Abbreviations \\ MRSA: Methicillin-Resistant Staphylococus aureus; PFGE: Pulsed-Field Gel Electrophoresis; spa: Staphylococcal protein A}

\section{Funding}

This study was financially supported by Cukurova University Scientific Research Projects (TF2012LTP40/TSA-2016-5577), Adana, Turkey.

\section{Availability of data and materials}

The datasets used and/or analysed during the current study available from the corresponding author on reasonable request.

\section{Authors' contributions}

YK collected samples, cultured the isolates, and performed DNA extraction. YK and TGG performed the statistical analyses. FK and AY designed the study. FK and AY supervised the practical work and data management. YK, TGG and FK wrote the manuscript. All authors approved the final version of the manuscript.

Ethics approval and consent to participate

Not applicable.

Consent for publication

Not applicable.

Competing interests

The authors declare that they have no competing interests.

\section{Publisher's Note}

Springer Nature remains neutral with regard to jurisdictional claims in published maps and institutional affiliations.

\section{Author details}

${ }^{1}$ Ceyhan Veterinary Faculty, Department of Microbiology, Cukurova University, 01930 Adana, Turkey. ${ }^{2}$ Microbiology Laboratory, Adana City Hospital, 01380 Adana, Turkey. ${ }^{3}$ Department of Microbiology, Medical Faculty, Cukurova University, 01380 Adana, Turkey. ${ }^{4}$ Present address: Microbiology Laboratory, Adana City Hospital, 01380 Adana, Turkey.

Received: 27 May 2018 Accepted: 4 October 2018

Published online: 24 October 2018

\footnotetext{
References

1. Lowy FD. Staphylococus aureus infections. N Engl J Med. 1998;339:520-32.

2. Deurenberg $\mathrm{RH}$, Vink C, Kalenic S, Friedrich AW, Bruggeman CA, Stobberingh EE. The molecular evolution of methicillin resistant Staphylococcus aureus. Clin Microbiol Infect. 2007;13:222-35.

3. Cookson BD, Robinson DA, Monk AB, Murchan S, Deplano A, de Ryck R, Struelens MJ, Scheel C, Fussing V, Salmenlinna S, Vuopio-Varkila J, Cuny C, Witte W, Tassios PT, Legakis NJ, van Leeuwen W, van Belkum A, Vindel A, Garaizar J, Haeggman S, Olsson-Liljequist B, Ransjo U, Muller-Premru M, Hryniewicz W, Rossney A, O'Connell B, Short BD, Thomas J, O'Hanlon S, Enright MC. Evaluation of molecular typing methods in characterizing a
} 
European collection of epidemic methicillin-resistant Staphylococcus aureus strains: the HARMONY collection. J Clin Microbiol. 2007:45:1830-7.

4. Chung M, De Lencastre H, Matthews P, Tomasz A, Adamsson I, De Sousa MA, Camou T, Cocuzza C, Corso A, Couto I, Dominguez A, Gniadkowski M, Goering R, Gomes A, Kikuchi K, Marchese A, Mato R, Melter O, Oliveira D, Palacio R, Sa-Leao R, Sanches IS, Song JH, Tassios PT, Villari P. Molecular typing of methicillin-resistant Staphylococcus aureus by pulsed-field gel electrophoresis: comparison of results obtained in a multilaboratory effort using identical protocols and MRSA strains. Microb Drug Resist. 2000;6:189-98.

5. Murchan S, Kaufmann ME, Deplano A, de Ryck R, Struelens M, Zinn CE, Fussing V, Salmenlinna S, Vuopio-Varkila J, El Solh N, Cuny C, WitteW TPT, Legakis N, Van Leeuwen W, Van Belkum A, Vindel A, Laconcha I, Garaizar J, Haeggman S, Olsson-Liljequist N, Ransjo U, Coombes G, Cookson B. Harmonization of pulsed-field gel electro-phoresis protocols for epidemiological typing of strains of methicillin-resistant Staphylococcus aureus: a single approach developed by consensus in 10 European laboratories and its application for tracing the spread of related strains. J Clin Microbiol. 2003;41:1574-85.

6. Stefani S, Chung DR, Lindsay JA, Friedrich AW, Kearns AM, Westh $H$, Mackenzie FM. Meticillin-resistant Staphylococcus aureus (MRSA): global epidemiology and harmonisation of typing methods. Int J Antimicrob Agents. 2012;39:273-82.

7. Enright MC, Day NP, Davies CE, Peacock SJ, Spratt BG. Multilocus sequence typing for characterization of methicillin-resistant and methicillin-susceptible clones of Staphylococcus aureus. J Clin Microbiol. 2000;38:1008-15.

8. Shopsin B, Gomez M, Montgomery SO, Smith DH, Waddington M, Dodge DE, Bost DA, Riehman M, Naidich S, Kreiswirth BN. Evaluation of protein a gene polymorphic region DNA sequencing for typing of Staphylococcus aureus strains. J Clin Microbiol. 1999;37:3556-63.

9. Strommenger B, Kettlitz K, Weniger T, Harmsen D, Friedrich AW, Witte W. Assignment of Staphylococcus isolates to groups by spa typing, Smal macrorestriction analysis, and multilocus sequence typing. J Clin Microbiol. 2006:44(7):2533-40.

10. EUAST: European Committee on antimicrobial susceptibility testing guide August 2016: 2016. Clinical breakpoint (http://www.eucast.org/fileadmin/src/ media/PDFs/EUCAST_files/QC/N_8.0_EUCAST_QC_tables_routine_and_ extended_QC.pdf). Accessed 12 May 2016.

11. Mulvey MR, Chui L, Ismail J, Louie L, Murphy C, Chang N, Alfa M. Development of a Canadian standardized protocol for subtyping methicillin-resistant Staphylococcus aureus using pulsed-field gel electrophoresis. J Clin Microbiol. 2001;39:3481-5.

12. Harmsen D, Claus H, Witte W, Rothgänger J, Claus H, Turnwald D, Vogel U. Typing of methicillin-resistant Staphylococcus aureus in a university hospital setting by using novel software for spa repeat determination and database management. J Clin Microbiol. 2003;41:5442-8.

13. Otter JA, French GL. Community-associated meticillin-resistant Staphylococcus aureus strains as a cause of healthcare associated infection. J Hosp Infect. 2011:79(3):189-93.

14. Grundmann H, Aanensen DM, van den Wijngaard CC, Spratt BG, Harmsen D, Friedrich AW. Geopraphic distribution of Staphylococcus aureus causing invasive infection in Europe: a molecular-epidemiological analysis. PLoS Med. 2010;7(1):e1000215.

15. Johnson AP. Methicillin-resistant Staphylococcus aureus: the European landscape. J Antimicrob Chemother. 2011;66(4):43-8.

16. Song JH, Hsueh PR, Chung DR, Ko KS, Cl K, Peck KR, Yeom JS, Kim SW, Chang HH, Kim YS, Jung SI, Son JS, So TM, Lalitha MK, Yang Y, Huang SG, Wang H, Lu Q, Carlos CC, Perera JA, Chiu CH, Liu JW, Chongthaleong A, Thamlikitkul V, Van PH. Spread of methicillin-resistant Staphylococcus aureus between the community and the hospitals in Asian countries: an ANSORP study. J Antimicrob Chemother. 2011;66:1061-9.

17. Chen H, Liu Y, Jiang X, Chen M, Wang H. Rapid change of methicillinresistant Staphylococcus aureus clones in a Chinese tertiary care hospital over a 15-year period. Antimicrob Agents Chemother. 2010;54(5):1842-7.

18. Ho CM, Ho MW, Lee CY, Tien N, Lu JJ. Clonal spreading of methicillinresistant SCCmec Staphylococcus aureus with specific spa and dru types in Central Taiwan. Eur J Clin Microbiol Infect Dis. 2012;31(4):499-504.

19. Dulon M, Haamann F, Peters C, Schablon A, Nienhaus A. MRSA prevalence in European healthcare settings: a review. BMC Infect Dis. 2011;11:138.
20. Vainio A, Koskela S, Virolainen A, Vuopio J, Salmenlinna S. Adapting typing for national laboratory-based surveillance of methicillin-resistant. Eur J Clin Microbiol Infect Dis. 2011;30(6):789-97.

21. Teixeira LA, Resende CA, Ormonde LR, Rosenbaum R, Figueiredo AM, De Lencastre H, Tomasz A. Geographic spread of epidemic multiresistant Staphylococcus aureus clone in Brazil. J Clin Microbiol. 1995;33:2400-4.

22. Ergon MC, Biçmen M, Gülay Z. Dokuz Eylül Üniversitesi Hastanesindeki dominant metisiline dirençli Staphylococcus aureus suşunun moleküler yöntemlerle tiplendirilmesi. ANKEM Derg. 2010;24(2):65-70.

23. Alp E, Klaassen CHW, Doğanay M, Altoparlak Ü, Aydin K, Engin A, Kuzucu Ç, Özakin C, Özinel MA, Turhan Ö, Voss A. MRSA genotypes in Turkey: persistence over 10 years of a single clone of ST239. J Inf Secur. 2009:58:433-8.

24. Yılmaz ŞK, Acuner IÇ, Strommenger B, Bek Y, Witte W. Türkiye'nin Orta Karadeniz bölgesinde metisiline dirençli Staphylococcus aureus kökenlerinin enfeksiyözite-rezistotip-genotip kümelenmesi. Mikrobiyol Bül. 2014;48(1):14-27.

25. Bozdoğan B, Yıldız Ö, Oryaşın E, Kırdar S, Gülcü B, Aktepe O, Arslan U, Bayramoğlu G, Çoban AY, Coşkuner SA, Güdücüoğlu H, Karabiber N, Öncü S, Tatman M, Özkütük N, Özyurt M, Şener AG. t030 is the most common spa type among methicillin-resistant Staphylococcus aureus strains isolated from Turkish hospital. Mikrobiyol Bul. 2013;47(4):571-81.

26. Fetscha A, Contzenb M, Harteltc K, Kleiserd A, Maassene S, Raub J, Kraushaara B, Layerg F, Strommenger B. Staphylococcus aureus foodpoisoning outbreak associated with the consumption of ice-cream. Int Food Microbiol. 2014;187:1-6.

27. Otter JA, French GL. The emergence of community-associated methicillinresistant Staphylococcus aureus at a London teaching hospital, 2000-2006. Clin Microbiol Infect. 2008;14:670-6.

28. Franco A, Hasman H, lurescia M, Lorenzetti R, Stegger M, Pantosti A, Feltrin F, lanzano A, Porrero MC, Liapi M, Battisti A. Molecular characterization of spa type t127, sequence type 1 methicillin-resistant Staphylococcus aureus from pigs. J Antimicrob Chemother. 2011;66(6):1231-5.

\section{Ready to submit your research? Choose BMC and benefit from}

- fast, convenient online submission

- thorough peer review by experienced researchers in your field

- rapid publication on acceptance

- support for research data, including large and complex data types

- gold Open Access which fosters wider collaboration and increased citations

- maximum visibility for your research: over 100M website views per year

At BMC, research is always in progress.

Learn more biomedcentral.com/submissions 